\title{
Regulation of Land Lease Rights Period for Foreign Citizens in Indonesia
}

\author{
Putu Rosa Paramitha Dewi' \& I Nyoman Budiana² \\ Undiknas Pasca Sarjana, Denpasar, Bali. \\ rosaparamithadewi@gmail.com¹ \& budiananyoman1961@gmail.com²
}

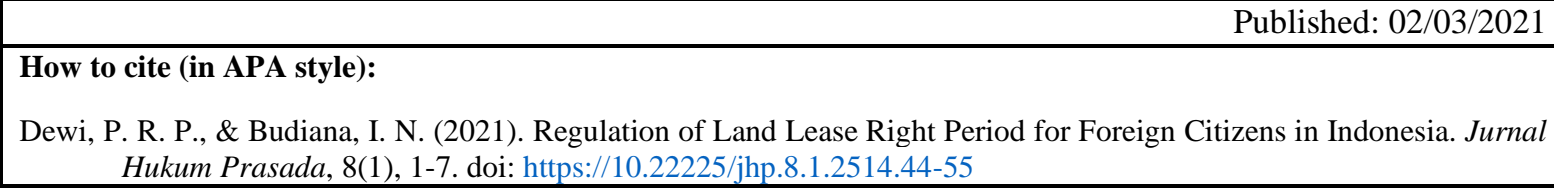

\begin{abstract}
Many foreigners have come and lived in Indonesia. This results in the increasing need for land and buildings for foreigners to be used as a residence. Foreigners are not allowed to have ownership rights over land in Indonesia, however, in this case, the law provides rights for foreigners to own land in Indonesia, but limited to Right of Use and Leaseholds for Buildings. This absence of UUPA has the potential to lead to smuggling of laws, because the lease period granted to foreign citizens is not limited so that foreign citizens can stay in Indonesia for a very long. If the land is fully controlled by foreign citizens or for a long period of time, it is feared that the people's welfare will decrease in the management of the land. Therefore, this study aims to analyze the legal of land right for foreign citizens in Indonesia and the regulation of the period of land lease right for foreign citizens in Indonesia. The type of research used is a normative juridical research through a statutory approach, a case approach, and a conceptual approach. A foreign legal entity wishing to have Building Use Rights (HGB) must fulfill two elements, namely that it is established according to Indonesian law and domiciled in Indonesia, must exist. Besides that, regulation for the period of land lease rights for foreigners have not been regulated in land-related regulations in Indonesia so that there is a vacuum of norms.
\end{abstract}

Keywords: Foreign citizens; Land; Lease rights; Regulation

\section{INTRODUCTION.}

Recently, many foreign citizens have come and lived in Indonesia. Foreigners have a high interest in Indonesia. Foreigners come to Indonesia not only for travel, but many have decided to work and live permanently in Indonesia. Foreigners need a place to live or a residential house to support their activities in Indonesia. This results in the increasing need for land and buildings for foreigners to be used as a residence and of course they also want to have rights to these lands and buildings.

Land is one of the most basic assets of the Indonesian state, because the state and nation live and develop on land. The Indonesian people consider land to be very important, because it is a major factor in increasing agrarian productivity. Land is a surface of the earth that is above once. The meaning of the surface of the earth as part of the land whose rights can be owned by any person or legal entity (Supriadi, 2010). Land has a very important role in human life because it can determine the existence and continuity of relationships and legal actions, both in terms of individuals and impacts on others and to prevent land problems from creating conflicts of interest in society, it is necessary to regulate, control and use land or in other words it is called the law of the land. The laws and regulations in Indonesia that specifically regulate land are Law No. 5/1960 on Basic Agrarian Principles (hereinafter as UUPA). The state is given the authority as the supreme power organization of the Indonesian Nation to regulate and administer the designation, use, supply and maintenance of earth, 
water and space, determine and regulate legal relations between people and earth, water and space. as well as determining and regulating legal relationships between people and various laws concerning earth, water and space based on Article 2 paragraph (2) of the UUPA. The functions and duties of the state as an organization of power for all the Indonesian people are the processes, methods or actions of the earth, water and space which are used to achieve the maximum possible prosperity for the people in the sense of nationality, welfare and independence in an independent, sovereign Indonesian society and state of law, fair and prosperous (Santika, 2017).

The UUPA regulates the prohibition of land tenure by foreigners. This is a reflection of the principle of nationality as regulated in Article 21 paragraph 1 of the UUPA, which stipulates that "only Indonesian citizens can have property rights". The principle of nationality is an attitude of the Indonesian nation that places the national interest above the interests of everything, towards this there is no compromise to sacrifice the interests of other countries. That is, full sovereignty over the earth, space water and the natural resources that exist in this country as a result of independence aimed solely for the general welfare of its people. Based on the principle of nationality contained in the UUPA, basically differentiates ownership of land rights between Indonesian citizens and foreign citizens. Foreigners are not allowed to have ownership rights over land in Indonesia, however, the enactment of the UUPA does not mean that it does not provide opportunities for foreigners to own land in Indonesia, in this case, the law gives foreigners the right to own land in Indonesia, but only limited to the right to use and lease rights for buildings.

Arrangements period Right of Use, Building Use Rights, and Business Use Rights have been described in UUPA but it can be seen that there is no regulation lease rights period for buildings for foreigners in the UUPA or in government regulations under it. The lease period for a building for foreigners is only based on the agreement between the lessee and the lessee. The term of building lease rights for foreigners has not been further regulated in the statutory regulations in the land sector, therefore there is a vacuum of norms due to the absence of detailed arrangements for lease rights for buildings for foreign citizens (WNA). The absence of these norms has the potential to lead to smuggling of laws, because there is no regulation regarding the period for granting lease rights to foreign citizens, the lease period granted to foreign citizens is not limited so that foreign citizens can stay in Indonesia for a very long time because they think that own property in Indonesia under a lease agreement.

The absence of norms or the absence of norm regulations that limit the lease period for foreigners, as if foreign citizens can own land or buildings in Indonesia for a very long period of time and these actions can injure the Nationality Principle contained in the UUPA. Apart from that, there is also concern that the absence of norms regulating the period of granting of lease rights for foreign citizens means that foreign citizens can control land or buildings in Indonesia under the guise of a lease agreement. If the land is fully controlled by foreign citizens or for a long period of time, it is feared that the people's welfare will decrease in the management of the land. Based on the description above, therefore, this study aims to analyze the legal of land right for foreign citizens in Indonesia and the regulation of the period of land lease right for foreign citizens in Indonesia.

\section{LITERATURE REVIEW}

a. Theory Gradual.

Land is one of the gifts created by God Almighty to mankind. Land can be said to have become a basic human need. Humans in carrying out their lives really need land to be used as a place to live and a source of livelihood. Cosmologically, land is a place where humans live, work, and live, where they come from and where they go (Limbong, 2014). Realizing the importance of regulations related to land use, the constitution of the Republic of Indonesia has formulated the basis for regulating land and other natural resources, in which Article 33 paragraph 3 of the 1945 Constitution states that the earth, water and natural resources contained therein are controlled by the State and used as much as possible for the prosperity of the people. This provision shows an imperative nature because it contains an order to the 
State that the earth, water and natural resources contained therein which are placed under the control of the State are used maximally to create welfare for all Indonesian people (Muchsin \& Soimin, 2014). Land rights are rights that give the right holder the authority to use and / or benefit from the land they own. Land rights are closely related to the use of the land itself and in other words, land rights are rights to control of land which contain the authority, obligations and / or prohibitions for the right holder to do something on the land which he is entitled to, whether an act that is permissible, obligatory or otherwise which is forbidden to do. The basis for regulating land rights as stipulated in Article 4 paragraph (1) of the UUPA states that on the basis of the State's right to control as referred to in Article 2, it is determined that there are various rights over the earth's surface, called land, which can be given to and owned by people either alone or together with other people and legal entities. On the basis of these provisions, UUPA describes the types of land rights in Article 16 paragraph (1), namely property rights, land use rights, building rights, usage rights, lease rights, land opening rights, and forest harvesting rights.

The right to lease for buildings is the right to use land owned by others for building purposes, by paying the owner an amount of rent (Hajati, Winarsi, Sekarmadji, \& Moechthar, 2017). Lease rights for buildings can occur with the existence of a land lease agreement between the owner of the land title and the land tenant or what is known as the party who holds the lease for the building. If it is related to the applicable contract law in Indonesia, the lease agreement can be carried out orally or in writing either under hand or with an authentic deed made by a public official, in this case a notary.

Based on their presence in Indonesia, foreigners can be divided into two, namely first, foreigners who reside in Indonesia permanently (Indonesian residents with a permanent residence permit), second, foreigners who do not live permanently in Indonesia but only occasionally stay in Indonesia ( with a visit permit / other immigration permit either a passport or other immigration documents (Hajati et al., 2017). Regarding land rights for foreign citizens in Indonesia, the UUPA states that foreigners who can have use rights and lease rights for buildings are foreigners who are domiciled in Indonesia, although the UUPA does not explain further what is meant by domiciling in Indonesia.

Legal discovery is a method of obtaining laws when the rules do not exist, and it is not clear how they apply to a concrete case. According to Mertokusumo (2007) in his book, it is impossible for a law to cover all human activities, so there is no statutory regulation that is complete and clear. The discovery of the law is something other than the mere application of rules to events.

\section{b. Theory of Legal Philosophy.}

Gustav Radbruch, originator of the three basic values of law from Germany, once said that a good law is when the law contains the values of justice, legal certainty and benefits. It is hoped that law enforcement will compromise the three elements. The three elements must receive balanced proportional attention. But in practice it is not always easy to work out a proportionally balanced compromise between the three elements. The idea of law can be understood as a thought construction which is an imperative to direct the law to the ideals desired by society. Gustav Radbruch argues that the ideal of law serves as a measure that is both regulative and constructive. Without a legal ideal, the resulting legal product will lose its meaning.

\section{METHOD}

a. Type of Research.

This type of research used in this paper is normative legal research. The type of normative legal research is chosen because this research describes the existing problems, which is then discussed with a study based on legal theories then linked to the applicable laws and regulations in legal practice. This normative research focuses on written regulations (law in book). The statutory approach examines and analyzes all laws and 
regulations relating to the legal issue being addressed. The legal approach that the author uses in this paper is:

1. The 1945 Constitution of the Republic of Indonesia

2. The Civil Code

3. Basic Agrarian Law

4. Government Regulation Number 103 of 2015 concerning Ownership of Residential or Occupancy by Foreigners Domiciled in Indonesia (State Gazette of the Republic of Indonesia of 2015 Number 325, Supplement to State Gazette Number 5793), (hereinafter referred to as Government Regulation Number 103 of 2015) which is promulgated in Jakarta on December 28, 2015, based on the preamble of PP No. 103 of 2015 letter a as new regulations that are valid until now. 1 PP No. 103 of 2015

The conceptual approach is an approach that studies doctrines and views in legal science. The author finds ideas that define law by studying legal concepts and principles related to the title of this thesis. The views of legal experts used in this study are the views of experts regarding the principle of legal discovery related to the absence of law and Gustav Radbruch's view of the legal ideals which consist of justice, legal certainty and benefit.

b. Type of Data.

The type of data used is primary, secondary, and tertiary data described as following:

1) Primary legal materials, UUD NRI 1945, KUHPer, Law Number 5 of 1960 concerning Basic Agrarian Regulations (State Gazette of the Republic of Indonesia Number 104 of 1960, Supplement to State Gazette Number 2043), (hereinafter abbreviated to UUPA), Government Regulation Number 103 of 2015 concerning Ownership of Residential or Residential Houses by Foreigners Domiciled in Indonesia (State Gazette of the Republic of Indonesia of 2015 Number 325, Supplement to State Gazette Number 5793), (hereinafter referred to as PP Number 103 of 2015).

2) Secondary legal materials include legal books, legal journals, legal papers or views of legal experts published in mass media.

3) Tertiary legal materials are in the form of materials that can provide guidance and explanation for primary and secondary legal materials, such as the Big Indonesian Dictionary, encyclopedias, as well as information from relevant and reliable internet.

c. Technique of Collecting Legal Material.

Technique of collecting legal materials used in this research is through literature study. Legal materials obtained through library research are first carried out by understanding and examining the contents in depth and then making notes according to the problems studied, either directly or indirectly. Collection of relevant materials, books or reading materials or scientific works of scholars. The analysis of the legal material of this thesis is done by:

1) Description, is a basic analysis that cannot be avoided, description means a description of what is to a legal or non-legal condition. In this study, there is a condition where there is no regulation regarding the term of land lease rights for foreigners. This arrangement is very important because in fact currently there are so many foreign citizens who rent land in Indonesia but there is no legal certainty about the legal provisions.

2) Interpretation is in the form of using types of interpretation in legal science such as systematic interpretation and grammatical interpretation.

1. Systematic interpretation is the interpretation of laws by connecting one article to another in a statute or with other laws. 
2. Grammatical Interpretation, namely interpreting the law according to the meaning of the word (term). Between language and law there is a very close relationship. Language is the only means by which legislators express their will, but sometimes legislators are unable to put together the right words.

3) Systematization technique is carried out by means of mesistematics of written legal materials. Systematization is making a classification or division of these legal materials to facilitate analysis and construction work (Soekanto \& Mamudji, 2006).

\section{RESULT AND DISCUSSION}

\section{Legal Analysis of Land Rights for Foreign Citizens in Indonesia}

The provisions governing land rights, including who can own certain land rights are contained in the Basic Agrarian Law, namely Law Number 5 of 1960 concerning Basic Agrarian Regulations and Government Regulation Number 40 of 1996 concerning Hak Guna Usaha, Hak Guna Bnagunan, and Land Use Rights (Right of Use). Land rights are rights that give the right holder the authority to use and / or take advantage of the land he has held. Land rights are inherent rights and cannot be just removed. The legal provisions on land rights are based on Article 4 paragraph (1) of the UUPA which states that: "On the basis of the state's right to control over land as referred to in Article 2 it is determined that there are various rights over the surface of the earth, called land, which can be granted. to and owned by persons, individually or collectively with other persons and legal entities. ". Authority in land rights is stated in 38 Article 4 paragraph (2) of the Basic Agrarian Law, namely to use the land concerned, as well as the body of the earth and water and the space on it are only needed for interests directly related to the land within the boundaries - limits according to this Law and other higher legal regulations (Urip, 2008). The legal basis for the provision of land rights is regulated in Article 4 paragraph (1) of the Basic Agrarian Law that based on the state's right to control over land, it is determined that there are various rights over the surface of the earth called land which can be given to and owned by people. - people either alone or together with other people and legal entities" (Urip, 2008). The types of land rights referred to in Article 4 of the Basic Agrarian Law above are determined in Article 16 paragraph 1 of the Basic Agrarian Law, namely:

a. Right of ownership;

b. Cultivation Rights;

c. Building rights;

d. Use Rights;

e. Lease Right;

f. Right to open land;

g. The right to collect forest products;

Other rights that are not included in the aforementioned rights which will be stipulated by law as well as rights which are temporary as mentioned in Article 53 production sharing, boarding rights and agricultural land lease rights. The land rights are regulated to limit their properties which are contrary to the Basic Agrarian Law and these rights are sought to be eliminated in a short time.

Types of Land Rights:

a. Right of ownership

Based on Article 570 of the Indonesian Criminal Code, it is stated that property rights are the right to enjoy the use of something material freely, and to act freely on that material with full sovereignty as long as it is not at fault with laws or general regulations stipulated by a power that has the right to reside and does not interfere with rights. -Right of others without prejudice to the possibility of revocation of that right for the public interest based on the provisions of law and with compensation. Based on Article 21 paragraph 1 of the Basic Agrarian Law, only Indonesian citizens can have property rights so that foreigners are not allowed to own property rights. However, there are several things that can cause these foreigners to acquire land with ownership rights status. This provision is contained 
in Article 21 paragraph 3 of Law Number 5 of 1960, namely "Foreigners who after the enactment of this Law obtain property rights because of inheritance without will or mixing of assets due to marriage, as well as Indonesian citizens who have property rights and After the enactment of this law, loss of citizenship is obliged to give up said right within a period of one year from the acquisition of said right or loss of citizenship. If after that period, the ownership rights are not relinquished, then the right is canceled because the law and land fall on the state, provided that the rights of the other party continue to impose them.

\section{b. Cultivation Rights}

Based on Article 28 paragraph (1) of the Basic Agrarian Law Number 5 of 1960 ("UUPA"), the right to cultivate land that is directly controlled by the State, within a certain period, for agricultural, fishery or livestock companies (" HGU "). Apart from UUPA, other regulations governing HGU are Government Regulation No. 40/1996 concerning Business Use Rights, Building Use Rights and Land Use Rights ("PP No. 40/1996"). In PP No.40 / 1996, it is further regulated regarding HGU. Only Indonesian citizens and legal entities established under Indonesian law and domiciled in Indonesia can hold HGU. If the HGU holder does not fulfill the requirements as an Indonesian citizen and is not an Indonesian legal entity domiciled in Indonesia, then the HGU holder is obliged to release or transfer the HGU to another eligible party within a period of 1 (one) year. If it is not released or transferred, the HGU will be removed and the land status will return to state land. HGU can be granted for a maximum period of 25 years. Companies that need a longer period of time can be granted a HGU for a maximum period of 35 years. At the request of the HGU holder and considering the condition of the company, the period can be extended for a maximum period of 25 years.

\section{Building rights}

Building use rights (HGB) are mentioned in Article 16 paragraph (1) letter $\mathrm{c}$ of the Basic Agrarian Law. Building use rights are specifically regulated in Article 35 to Article 40 of the Basic Agrarian Law. According to Article 50 paragraph (2) of the Basic Agrarian Law, more provisions regarding Building Use Rights are regulated by statutory regulations. The statutory regulations referred to here are Government Regulation Number 40 of 1996 concerning Business Use Rights, Building Use Rights and Land Use Rights. HGB is the right to construct and own a building on land owned by another party for a maximum period of 30 years and can be extended for 20 years. If it has expired, the user of this right can apply for a renewal of rights for another 30 years. HGB is transferable. SHGB can only be obtained by Indonesian citizens and companies that are established under Indonesian law and domiciled in Indonesia. With the enactment of Law no. 25 of 2007 concerning Investment, then the period of the HGB is extended, based on Article 22 paragraph (1) letter b, namely: "Building Use Rights can be granted for a total of 80 (eighty) years by means of being granted and extended in advance all at once for 50 years. (fifty) years and can be renewed for 30 (thirty) years. "SHGB status can be upgraded to SHM in accordance with applicable regulations. SHGB can also be a guarantee to third parties and can be used in capital participation. HGB can be revoked if the land is needed for development of public interest.

\section{d. Use Right}

The definition of Use Rights is stated in Article 41 paragraph (1) of the UUPA, namely the right to use and / or collect proceeds from land that is directly controlled by the state or land owned by another person, which gives the authority and obligations determined in the decision to grant it by the official authorized to grant it. or with an agreement with the land owner, which is not a lease agreement or an agreement for land management, everything as long as it does not conflict with the spirit and provisions of the UUPA. The word "use" in Right of Use refers to the notion that Right of Use is used for the purpose of constructing buildings, while the word "collecting results" in Right of Use refers 
to the notion that the right to use is used for the purposes of agriculture, fisheries and livestock and plantations.

Based on Article 42 UUPA stipulates that those who can have usufructuary rights over land include:

1. Indonesian citizen;

2. Foreigners who are domiciled in Indonesia;

3. A legal entity established under Indonesian law and domiciled in Indonesia;

4. Foreign legal entities that have representatives in Indonesia.

The Right to Use Certificate also has a usage time limit, in accordance with Government Regulation (PP) Number 103 of 2015, which states that the Right to Use has a validity period of not more than 30 (thirty) years. However, it can be extended for 20 (twenty) years and then renewable for another 30 (thirty) years according to the agreement with the land rights holder.

\section{e. Lease Right}

The Basic Agrarian Law (UUPA) contains the main provisions regarding lease rights, namely in Article 44 and Article 45. Provisions regarding lease rights are also contained in Article 50 Paragraph (2). However, until now, there are no complete implementing regulations regarding the lease rights. Based on the formulation of Article 44 of the UUPA, we can conclude that land leasing between the parties is only allowed if the land being leased has the status of property rights. UUPA, although the UUPA did not explicitly revoke it. This is to prevent legal dualism that would conflict with the spirit of the UUPA. The right to rent for buildings is the right to use land owned by others for building purposes, by paying the owner an amount of rent (Hajati et al., 2017).

The UUPA does not regulate how long period for the right to lease for buildings. Regarding this period, it is submitted to the agreement between the land owner and the holder of the lease rights for buildings (Hajati et al., 2017). Lease rights for buildings can occur with the existence of a land lease agreement between the owner of the land title and the land tenant or what is known as the party who holds the lease for the building.

\section{f. The right to open land}

The right to open land and collect forest products can only be owned by Indonesian citizens and is regulated by statutory regulations (Article 46 UUPA).

\section{g. The right to collect forest products}

The right to collect forest products is given by the government to citizens who are the government's contribution in providing welfare to the citizenry. The collection of forest products comes from wood and non-timber products.

Based on the descriptions above, not all land rights can be owned by foreigners. Based on the UUPA, land rights such as ownership, rights to open land, and the right to collect forest products can only be owned by Indonesian citizens. Then the Right to Cultivate (HGU) can only be owned by Indonesian citizens and legal entities domiciled in Indonesia so that the HGU cannot be owned by foreigners, legal entities that can have these rights are only legal entities with national capital. For legal entities with foreign capital, the possibility to use land use rights is only opened if it is required by the governing law (Sembiring \& Simatur, 2010). Then the Building Use Rights (HGB) also cannot be owned by foreign citizens. If a foreign legal entity wishes to have Building Use Rights (HGB), then two elements, namely being established according to Indonesian law and domiciled in Indonesia, must exist. So that only Indonesian citizens can have this Building Use Right.

The rights to land that can be owned by foreign citizens (WNA) are only limited to the right to use (HP) and the right to lease for buildings according to the provisions in the UUPA. The rights given to foreigners by the government are stated to be sufficient to give roles to foreigners to participate in development in Indonesia. These rights are given to 
foreigners to advance the economy in Indonesia without injuring the principle of nationality and the principle of nationality adopted in the UUPA. This is broadly regulated in Article 41 \& Article 42 of the Basic Agrarian Law (UUPA) and is further regulated in PP. 40 of 1996 concerning Building Use Rights (HGB), Business Use Rights (HGU) and Use Rights (HP) on land.

The first discussion, the author will use the principle of legal discovery because in this case there is a norm vacuum against laws or regulations regarding land, especially regarding lease rights for foreign citizens in Indonesia. The process of legal discovery is usually carried out by forming the law by judges or other law enforcement officials in the application of general regulations to concrete legal events and the results of legal findings become the basis for making decisions. This absence of norms has the potential to lead to smuggling of laws, because there is no regulation regarding the period for granting lease rights to foreign citizens, the lease period granted to foreign citizens is not limited so that foreign citizens can stay in Indonesia for a very long time because they think that they have Owning property in Indonesia on the basis of a lease agreement, it is necessary to find legal findings related to regulating the term of the lease rights for foreign nationals so as not to injure the principle of Indonesian nationality contained in the UUPA.

\section{Regulation of the period of land lease rights for foreign citizens in Indonesia}

Regarding the absence of norms contained in the UUPA and other arrangements for land rights, none of them regulates the term of the lease rights for foreigners. As a result of the absence of norms, matters or circumstances that are not or have not been regulated can result in legal uncertainty (rechtsonzekerheid) or uncertainty of legislation in society which will further result in legal chaos (rechtsverwarring), in the sense of that as long as it is not regulated it means that it is permissible, as long as there is no clear and regulated procedure it means that it is not allowed. This is what causes confusion or confusion in society regarding what rules should be used or applied.

In the UUPA, on Business Use Rights (HGU), Building Use Rights (HGB), and Right to Use (HP), the term of ownership of these rights has been regulated but nothing regulates the duration of lease rights for foreigners in Indonesia so that there is a vacuum in norms for Laws or regulations regarding land, for this reason, it is necessary to add an article regarding the period of lease rights for foreigners. So far, the right to lease for foreigners is only based on a lease agreement, both underhanded agreements and agreements made by a notary. The lease term by foreigners that is not regulated by this law gives rise to freedom for foreigners to be able to have land rights in Indonesia, both for residence, place of work, etc. The period of time is not limited, even more than the term of other land rights such as HGB and Right of Use.

Based on UUPA, the process of submitting land rights such as HGB and Right of Use is quite difficult and has to go through a long process but the basis of lease rights for foreigners which is only based on a lease agreement between the parties results in freedom for foreigners to obtain lease rights and long stay In Indonesia, even the old lease rights can be inherited to the heirs of the tenants and it can be said that foreigners have rights to land that have the same status as property rights and this is clearly looking for the principle of nationality in the UUPA. Lease agreements by foreigners usually last for an unreasonable period of time, even up to a period of 100 or a lifetime. Lease rights can also be inherited to the heirs of the lease rights holder, in this case a foreigner. So that foreigners in other words can own land in Indonesia under the guise of lease rights. So that the lease agreement has the potential for legal smuggling because the time frame is unreasonable and exceeds the time limit of land rights for foreigners (right to use and right to build) and deviates from the principle of nationality and the provisions of the Article of the principle of nationality as regulated in Article 21 paragraph 1 UUPA, which states that "only Indonesian citizens can have property rights". Law smuggling is meant to deviate from Article 26 Paragraph (2) of the UUPA, namely:

a. Providing rental rights for buildings with lease periods that exceed the reasonable limit.

b. The rent paid is actually the actual land price. 
c. The land owner can only reclaim his land by paying back the amount of the land price. Lease agreements that exceed the reasonable limit for foreigners should also be null and void based on Article 26 Paragraph (2) of the UUPA which states:

"Every sale and purchase, exchange, gift, gift with will and other actions intended to directly or indirectly transfer property rights to a foreigner, to a citizen of which apart from Indonesian citizenship has foreign citizenship or to a legal entity, unless stipulated by the government, namely legal entities that can have property rights and the conditions thereof, are null and void because the law and land fall to the state, provided that the rights of the other party that impose them continue and all payments received by the owner cannot be sued again. "

Based on the description above, the regulation of the term of land lease rights for foreigners has not been regulated in land-related regulations in Indonesia, so there is a vacuum of norms and must be considered again by the government and other law enforcers to make legal findings to add articles regarding the period of land leases for foreigners so does not deviate from the principle of nationality of the Indonesian nation and does not reduce the welfare of the Indonesian people related to land management. Then there must be regulations for foreigners who can obtain land rights in Indonesia, especially the right to rent, must stay permanently in Indonesia, its presence provides benefits that can be proven through a Permanent Stay Permit Card (KITAP).

In the second discussion, the author uses Gustav Radbruch's Law of Idea Theory. Gustav Radbruch is the originator of three basic values of law from Germany, once said that good law is when the law contains the values of justice, legal certainty and benefits. It is hoped that law enforcement will compromise the three elements. The three elements must receive balanced proportional attention. Gustav Radbruch argues that the ideal of law serves as a measure that is both regulative and constructive. Without a legal ideal, the resulting legal product will lose its meaning. Gustav Radbruch taught that these three values must use the principle of priority where the first priority always falls on justice, only benefits, and lastly is legal certainty (Rawls, 2006):

1. Legal certainty.

Gustav Radbruch's Theory of Laws of Intent, in terms of legal certainty, should show a guarantee that the law (which contains the norms for advancing goodness) actually functions as a rule that should be obeyed. The legal duty ensures certainty in the relationships found in social interactions. Gustav Radbruch stated that:

"There are two definitions of law in developing countries about legal certainty, namely certainty due to law, and certainty in or from the law. Ensuring certainty because of the law becomes the duty of the law. A law that succeeds in guaranteeing a lot of certainty in social relations is a useful law. "

Legal certainty is beneficial for the community because they will know the clarity of their rights and obligations according to the law. Without legal certainty, people will not know what to do, not know whether their actions are right or wrong, prohibited or not prohibited by law. Regarding the above discussion, legal certainty is needed because there is no definite arrangement regarding the term of the lease rights for foreign citizens.

2. Legal Justice

According to Gustav Radbruch, justice and legal certainty are permanent parts of law. $\mathrm{He}$ is of the opinion that justice and legal certainty must be considered, legal certainty must be maintained for the sake of security and order of a country. Finally, positive law must always be obeyed. Based on the theory of legal certainty and the value to be achieved, namely the value of justice and happiness. Regarding the above discussion, legal justice is needed because there is no definite regulation regarding the term of the lease rights for foreign citizens. So that there is freedom for foreigners to get rental rights with an unlimited period of time. The term of the rental rights is not regulated like other land rights such as Right of Use or HGB. So that there are differences and there is a potential for legal smuggling due to the absence of norms. 
3. Legal benefit / finality

Etymologically, the word "benefit" comes from the root word "benefit", which, according to the Indonesian Dictionary, means use or use. Law is the lifeblood of a nation to achieve the ideals of a just and prosperous society. The benefit of law is the main objective of law and in this case it contains elements of relativity which can be derived from 3 types of subjects, namely: Individuals are humans as individuals, and laws are made with the aim of individuality so that the individual or his dignity is not only exalted but also given special protection.

a) Collectivity, that is, if the goal of law is the progress of the state, it will produce a collective legal system and is usually found in many socialist countries and;

b) Culture, namely the legal system created is a transpersonal legal system, aspects of culture or the results of civilization receive special attention, such as issues concerning democracy, human rights and the environment which are the affairs of all mankind guaranteed by international law.

The purpose of regulating agrarian affairs in Indonesia is to regulate how the Indonesian people can use the land and natural resources in the bowels of the Indonesian earth as well as possible for the prosperity of the Indonesian people. Land has a very important role in human life because it can determine the existence of and the continuity of relationships and legal actions, both in terms of individuals and impacts on others. In order to prevent land problems from creating conflicts of interest in the community, it is necessary to regulate, control and use land with the establishment of UUPA which aims to emphasize the key role of land, that the earth, water and space has a very important function to build a just and prosperous society. Control and enforcement of land is primarily focused on the realization of justice and prosperity in community development. Land is a very basic human need. Humans live in carrying out activities on the ground so that every time humans are always in contact with the land, it can be said that almost all human life activities, either directly or indirectly, always require land. Land has a very important role in the life of the Indonesian nation or in the implementation of national development which is organized as a sustainable effort to create a just and prosperous society based on Pancasila and the 1945 Constitution.

The principle of nationality contained in the UUPA also aims to require that only the Indonesian nation can have full legal relations with the earth, water, space and the wealth contained therein. The existence of the principle of nationality, there is a guarantee regarding the rights of Indonesian citizens to land ownership as well as those related to the earth, water and space and other natural resources contained therein so that foreign citizens or foreign business entities do not have ownership rights to land in Indonesia. Based on the above discussion, the legal benefits of UUPA must be considered. The addition of articles related to regulating the term of lease rights for foreigners is certainly very beneficial for Indonesian citizens and does not deviate from the principle of nationality that is upheld by the Indonesian nation.

As a basic value (legal principles) placing these three basic values as the first reference in the formation of statutory regulations. Legal objectives have goals to be achieved which divide rights and obligations between every individual in society. The theory of legal ideals can be understood as a construction of thought which is an imperative to direct the law to the ideals desired by society. Without legal ideals, the resulting legal product will lose its meaning (Kusumohamidjojo, 2016). So that in this study this theory is very useful in solving the problem formulation in this study in order to obtain legal certainty, justice, and benefits related to the period of granting lease rights to foreigners in Indonesia. If there is no legal certainty, foreigners can rent land and buildings for a period of time that exceeds the reasonable limit, namely more than 25 (twenty five) years and even up to 100 (one hundred) years. So that it is as if foreigners can own land or buildings in Indonesia for a very long time and this action can injure the principle of nationality contained in the UUPA.

\section{CONCLUSIONS AND SUGGESTIONS}

\section{a. Conclusion}


1. Based on the UUPA, not all land rights can be owned by foreigners. Right of ownership, rights to open land, and the right to collect forest products can only be owned by Indonesian citizens. Then Right of ownership (HGU) and Building Use Rights (HGB) can only be owned by Indonesian citizens too. For legal entities with foreign capital, the possibility to use land use rights is only opened if it is required by the governing law. Then a foreign legal entity wishing to have Building Use Rights (HGB) must fulfill two elements, namely that it is established according to Indonesian law and domiciled in Indonesia, must exist. Land rights that can be owned by foreigners are limited to the right to use (HP) and the right to lease for buildings according to the provisions in the UUPA. The rights given to foreigners by the government are stated to be sufficient to give roles to foreigners to participate in development in Indonesia.

2. Regulation for the period of land lease rights for foreigners have not been regulated in land-related regulations in Indonesia so that there is a vacuum of norms and must be reconsidered by the government and other law enforcers to make legal findings to add articles regarding the period of land leases for foreigners so as not to deviate the principle of the nationality of the Indonesian nation and does not reduce the welfare of the Indonesian people related to land management. Based on Gustav Radbruch's theory of ideals of law, it is imperative to direct the law to the ideals desired by society. Without legal ideals, the resulting legal product will lose its meaning. So that in this writing the theory of legal ideals is very useful in solving the problem formulation in this study in order to obtain legal certainty, justice, and benefits related to the period of granting lease rights to foreigners in Indonesia If there is no legal certainty, foreigners can rent land and buildings with a period that exceeds the reasonable limit of more than 25 (twenty five) years and even up to 100 (one hundred) years in this case as if a foreigner can own land or buildings in Indonesia for a very long period of time and such actions may injure the principle nationality contained in the UUPA.

\section{b. Suggestion}

The suggestions in this paper are intended for the Government or law enforcers to review and pay attention to the Law and Trade related to land in Indonesia so that they can add articles or form new rules regarding the term of lease rights for buildings, especially for foreigners, such as the appropriate period of time in the regulation. The term of other land rights such as Land Use Rights and Land Use Rights in order to create legal certainty and not injure the principle of Indonesian nationality as stated in the UUPA. Lease rights for foreigners should also go through the same provisions or process as applying for Use Rights or Building Use Rights so that foreigners do not easily have lease rights to land in Indonesia for a very long period of time. Then it is better if there should be arrangements for foreigners who can obtain land rights in Indonesia, especially the right to lease must stay permanently in Indonesia, its presence provides benefits that can be proven through a Permanent Stay Permit Card (KITAP).

\section{REFERENCES}

Hajati, S., Winarsi, S., Sekarmadji, A., \& Moechthar, O. (2017). Buku Ajar: Politik Hukum Pertanahan. Surabaya: Airlangga University Press.

Kusumohamidjojo, B. (2016). Teori Hukum: Dilema antara Hukum dan Kekuasaan. Bandung: Yrama Widya.

Limbong, B. (2014). Politik Pertanahan. Jakarta: Pustaka Margareta.

Mertokusumo, S. (2007). Penemuan Hukum. Yogyakarta: Liberty.

Muchsin, I. K., \& Soimin. (2014). Hukum Agraria Indonesia Dalam Perspektif Sejarah. Bandung: PT Refika Aditama.

Rawls, J. (2006). A Theory of Justice (Terjemahan). Yogyakarta: Pustaka Pelajar.

Santika, I. B. A. P. (2017). Pergeseran Makna Hak Menguasai Tanah oleh Negara dalam 
Pemanfaatan/Penggunaan Tanah untuk Investasi (1st ed.). Bandung: Serat Ismaya.

Sembiring, J. J., \& Simatur, Z. (2010). Panduan Mengurus Sertifikat Tanah. Jakarta: Visimedia.

Soekanto, S., \& Mamudji, S. (2006). Penelitian Hukum Normatif. Jakarta: Raja Grafindo Persada.

Supriadi. (2010). Hukum Agraria (4th ed.). Jakarta: Sinar Grafika.

Urip, S. (2008). Hukum Agraria dan Hak-Hak Atas Tanah. Jakarta: Kencana Prenadamedia Group.

UUD NRI 1945

Undang-undang Nomor 5 Tahun 1960 tentang Peraturan Dasar Pokok-pokok Agraria (selanjutnya disingkat UUPA).

Undang-Undang Pokok AgrariaPeraturan Pemerintah Nomor 103 Tahun 2015 tentang Pemilikan Rumah Tempat Tinggal atau Hunian oleh Orang Asing yang Berkedudukan di Indonesia (Lembaran Negara Republik Indonesia Tahun 2015 Nomor 325, Tambahan Lembaran Negara Nomor 5793), (selanjutnya disebut PP Nomor 103 Tahun 2015) yang diundangkan di Jakarta pada tanggal 28 Desember 2015, berdasarkan konsideran PP Nomor 103 Tahun 2015 huruf a sebagai peraturan baru yang berlaku hingga kini.1 PP Nomor 103 Tahun 2015 